\title{
SUITABILITY OF BURNT AND CRUSHED COW BONES AS PARTIAL REPLACEMENT FOR FINE AGGREGATE IN CONCRETE
}

\author{
N. M. Ogarekpe ${ }^{1,}{ }^{*}$, J. C. Agunwamba², F. O. Idagu ${ }^{3}$, E. S. Bejor ${ }^{4}$, O. E. Eteng5, H. E. Ndem ${ }^{6}$ and E. 0. Oloko ${ }^{7}$ \\ 1,3,4,5,6,7 Dept. OF Civil EngineERING, Cross River University of TeChnology, CALABAR, Cross River State NigERIA \\ 2 DEPARTMENT OF Civil ENGinEERING, UNIVERSITY OF NigERIA, NSUKKA, ENUGU STATE, NIGERIA \\ Email addresses:11 nkpaogarekpe@crutech.edu.ng, ${ }^{2}$ jonah.agunwamba@unn.edu.ng, ${ }^{3}$ idagufrancis@yahoo.com, \\ ${ }^{4}$ scholastica_ebaye@yahoo.com, ${ }^{5}$ peopleadviser@yahoo.com, 6 hope_edem@yahoo.com, ${ }^{7}$ emmanueloloko@ymail.com
}

\section{ABSTRACT}

The suitability of burnt and crushed cow bones (BCCB) as partial replacement for fine aggregate in concrete was studied. The percentages of replacements of fine aggregates of $0,10,20,30,40$ and 50\%, respectively of BCCB were tested considering 1: 2: 4 and 1: $11 / 2: 3$ concrete mix ratios. The cow bones were burnt for 50 minutes up to $92^{\circ} \mathrm{C}$ before being crushed. Ninety-six (96) concrete cubes of 1: 2: 4 mix ratio and ninety-six (96) concrete cubes of $1: 1 \frac{1}{2}: 3$ mix ratio measuring 150x150x150mm were tested for the compressive strength at 7, 14, 21 and 28 days respectively. The research revealed that the $B C C B$ acted as a retarder in the concrete. Water-cement ratio increased with the increase in the percentage of the $B C C B$. The mixes of 1:2:4 and 1:1 $\frac{1}{2}: 3$ at 28 days curing yielded average compressive strengths in $\mathrm{N} / \mathrm{mm}^{2}$ ranging from $16.49-24.29$ and $18.71-29.73$, respectively. For the mix ratios of 1:2:4 and 1:1 $\frac{1}{2}: 3$ at 28 days curing age, it was observed that increase in the BCCB content beyond 40 and $50 \%$, respectively resulted to the reduction of the average compressive strength below recommended minimum strength for use of concrete in structural works.

Keywords: Compressive strength, concrete, cow bone, fine aggregate, partial replacement

\section{INTRODUCTION}

Concrete is a mixture of hydraulic cement, aggregates, and water, with or without admixtures, fibres, or other cementitious materials [1]. Aggregates in concrete consist of sand and gravel, they represent the grain skeleton of the concrete. All cavities within this skeleton have to be filled with binder paste entirely to ensure quality [2]. According to the American Concrete Institute [1] fine aggregate is defined as: (i) "aggregate passing the $9.5 \mathrm{~mm}(3 / 8 \mathrm{in}$.) sieve, almost entirely passing the 4.75 $\mathrm{mm}$ (No. 4) sieve, and predominantly retained on the 75 $\mu \mathrm{m}$ (No. 200) sieve" and (ii) "That portion of aggregate passing the $4.75 \mathrm{~mm}$ (No. 4) sieve and predominantly retained on the $75 \mu \mathrm{m}$ (No. 200) sieve".

The gradation of sand is given by sieve analysis. This is done by passing sand through a set of standard sieves and finding out cumulative percentage passing through each sieve. When plotting an actual grading result, provided the "plot" remains within the zone/envelope the aggregate tested is within specification. If the line of the "plot" leaves the grading zone the aggregate sample is out of specification [3].

Concrete is a hardened composite stone made of predominantly Portland cement, water and aggregates.
Concrete consists of mineral aggregate in hardened cement paste. Since aggregates alone are a major component as it occupies about 75 percent by volume of concrete, it is not surprising that this constituent plays an important role in the fracture of the material [4].

In the past, researches have been carried out to ascertain the suitability of using waste products to produce lightweight concrete. Experiments have been performed to determine the suitability of using palm kernel shells as aggregate to produce lightweight aggregate concrete [5 9]. Abdullah [5] presented a range of 1725 to 2025 $\mathrm{kg} / \mathrm{m}^{3}$ for air dry densities of PKS concrete. Okafor [6] presented results which suggested that palm kernel shell cannot produce concrete with compressive strength above $30 \mathrm{MPa}$. Basri, et al [7] stated that the compressive strength of oil palm shell after 56 days was $41-50 \%$ lower than ordinary concrete. A trial mix design for concrete with oil palm shell (OPS) as coarse aggregate has resulted in strength of $24 \mathrm{~N} / \mathrm{mm}^{2}$ for 28-day [8].Teo et al. [9] summarised that OPS has good potential as a coarse aggregate for the production of structural lightweight concrete, especially for low-cost housing construction and also for use in earthquake prone areas.

\footnotetext{
* Corresponding author, tel: + 234-803-265- 1621
} 
Topcu [10] has also investigated the possibility of using volcanic slag as coarse aggregate in the production of semi-lightweight concrete. The results indicated that the volcanic slags can be safely used in the production of semi lightweight concrete [10].

Otunyo, et al [11] investigated the effect of sugar cane juice (SCJ) on slump values, setting times and strength of concrete. The study showed that the compressive strength of the (water: SCJ) concrete decreased as the percentage of SCJ increased up to $25 \%$ SCJ. Thereafter, an increase in compressive strength was noticed up till $100 \%$ SCJ, with a maximum strength of 13.08 $\mathrm{N} / \mathrm{mm}^{2}$ occurring at $100 \%$ SCJ at 28 days [11].

Egamana and Sule [12] determined an optimum compressive stress for periwinkle shell aggregate concrete. The optimum compressive strength was found to be $19.50 \mathrm{~N} / \mathrm{mm} 2$ corresponding to a mix ratio of 1:3:6 at a water-cement ratio of 0.65 . Adaba, et al [13] stated that the compressive strength at 28 day of crushed spent fire brick aggregate as partial replacement material was higher than the conventional river sand.

Javed, et al [14] carried out an exploratory study on the suitability of machine crushed animal bones as partial or full replacement for coarse aggregates in lightweight concrete. Our research herein presented, is on the suitability of burnt and crushed cow bones as partial replacement of fine aggregate in light weight concrete.

Across the world, cow bones constitute environmental problems in abattoirs. The foul odour emanating from clusters of cow bones are usually irritating and unwholesome where ever they are dumped. However, their reuse if perhaps found suitable in the BCCB concrete, could result in the sustainable development of the environment. This research is therefore aimed at determining the effect of burnt and crushed cow bones (BCCB) as partial replacement for fine aggregate in concrete. The specific objectives included the determination of: the effect of water cement ratio on BCCB as partial replacement for fine aggregate, the material characteristics and the effect of BCCB on compressive strength of concrete.

\section{MATERIALS AND METHODS}

\subsection{Materials}

The materials used for this study included: cement, river sand (fine aggregate), cow bones, gravel (coarse aggregate), water and digital handheld thermometer. The cow bones were burnt up to $92^{\circ} \mathrm{C}$ and crushed. The river sand used in this research work was obtained and sampled from the beach near Marina Resort in Calabar, Cross River State. Also, the United Cement Company of Nigeria (UNICEM) limestone Portland cement was used. Clean potable water free from all harmful matter was used for all the experiments. All aggregates were free of deleterious materials.

\subsubsection{Sample Collection}

The river sand and gravels collected in bags were taken to the laboratory where they were dried for $48 \mathrm{hrs}$ to reduce the moisture content after which the particle size distribution/sieve analysis and specific gravity test were determined. The coarse aggregate was thoroughly washed in order to reduce the clay content.

\subsection{Laboratory Test}

Several test and experiments were carried out at the civil engineering strength of materials laboratory of the Cross River University of Technology Calabar Campus. Generally, care was taken to ensure that the cement was stored in airtight bags in the laboratory to forestall the ingress of moisture.

\subsubsection{Laboratory tests on Aggregates}

The laboratory test on aggregates included the specific gravity, bulk densities, particle size distribution. Test on particle size distribution was done for both river sand and BCCB with sieve size ranging from $4.75 \mathrm{~mm}$ to pan. The particle size distribution was carried out in accordance with BS410 [15] and BS812 Part 103 [16]. The sample was washed clean. All excess free water was removed by careful decantation through the test sieve, avoiding transfer of solids. The residue was oven dried at $105 \pm 5{ }^{\circ} \mathrm{C}$ until constant mass was achieved. The sample was cooled, weighed and recorded. Sieves were assembled then placed in the ascending order of sieve numbers from $4.75 \mathrm{~mm}$ to pan. The sample was poured into the arranged sieves and placed on a mechanical shaker for 10 mins. The stacks were removed from the shaker and the weight of each sieve with its retained soil were recorded. Percentages retained and cumulative percentages passing were calculated.

\subsubsection{Slump Test}

Slump cone - a mould of $1.18 \mathrm{~mm}$ thick galvanized metal cone with frustum of base diameter of $200 \mathrm{~mm}$, top diameter $100 \mathrm{~mm}$ and height of $300 \mathrm{~mm}$. The base and the top were open and parallel to each other and at right angles to the axis of the cone. The mould was provided with a foot piece on each side for holding the mould in place, and with handles for lifting the mould from the sample. Tamping rod of a round, straight steel, $16 \mathrm{~mm}$ in diameter and approximately $600 \mathrm{~mm}$ in length. The tamping end had a hemisphere of diameter $16 \mathrm{~mm}$. The mould was oiled and placed on a flat, moist, nonabsorbent rigid surface. The cone was firmly positioned by standing on the two foot pieces. The cone was filled uniformly in 3 layers. Each layer was tamped 25 strokes of the tamping rod, the strokes distributed uniformly 
over the cross-section of the layer. The mould was removed from the concrete by raising it carefully in a vertical direction without lateral or torsion motion. The difference between the height of the mould and the height of the specimen at its highest point to the nearest $\mathrm{mm}$. This distance was the slump of the concrete.

\subsubsection{Compressive Strength Test}

The concrete compressive strength test was also performed to determine the compressive strength at various curing ages. Mixing was done manually with hand until all aggregates were homogenous. A standard mould of $150 \mathrm{~mm} \times 150 \mathrm{~mm} \times 150 \mathrm{~mm}$ was cleaned and oiled before use. Concrete was filled in the moulds. Each layer was compacted and tamped 35 times on each layer. Test specimens were remolded after 24 hours and cured in clear fresh water in a curing tank. Specimens were removed from the curing tank and excess water wiped out and weighed. Cubes were placed in compressive testing machine and load applied gradually without shock until the specimen fails. For each percentage of replacement and curing age, four cubes were made and compressively crushed in accordance with the specifications in BS1881 Part 116 [17]. A total of 192 cubes were made and crushed.

\subsection{Experimental Procedures and Analysis}

All test was carried out in accordance with the standard methods. Sieve analysis was carried out in accordance with the specifications in BS410 [15], while aggregates crushing was tested in accordance with the specification in BS812 Parts 110 [18]. BS882 [19] provided the envelope for aggregates from natural sources for concrete. BS1881, parts 102, 108, 114 and 116 [20 - 22, 17] provided guidelines for determination of slump, methods for making test cubes from fresh concrete, methods for determination of density of hardened concrete and method for determination of compressive strength of concrete cubes, respectively.

\section{RESULTS AND DISCUSSION}

\subsection{Effect of Water-Cement Ratio on BCCB as Partial Replacement for Fine Aggregate}

The results of the slump test are shown in Figure 1. The research revealed that the slump curves in Figure 1 show that the BCCB acts as a retarder thus the workability of concrete reduces with increase in BCCB implying that the water cement ratio increases with increase in percentage of BCCB. This was perhaps due to the shape of the particles of the BCCB thus affecting the cohesiveness of the concrete mix thereby causing collapse slump.

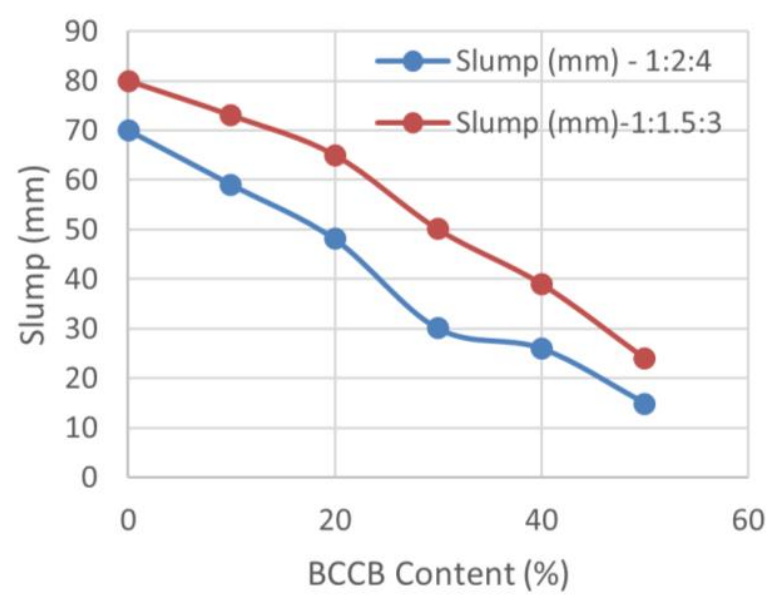

Figure 1: Slump test plot of BCCB as partial replacement for fine aggregate in concrete

\subsection{Material Characteristics and Classification}

Table 1 show the properties of aggregates and cement used in the research consequent upon laboratory test. The gradation of fine aggregates was carried out by determining the cumulative percentage passing through each sieve as specified in BS410. Figure 2 is the plot of the percentage passing of BCCB as compared to the standards specified by BS882. The computed coefficients of uniformity and curvature for the river sand (fine aggregates) and BCCB yielded $\mathrm{C}_{\mathrm{u}}=4.79, \mathrm{Cc}=0.73$ and $\mathrm{C}_{\mathrm{u}}=13.17, \mathrm{Cc}=1.79$, respectively. The particle size distribution curve of BCCB and the river sand are shown in Figures 2 and 3.The particle size distribution curve of the sand satisfies the requirement of lower and upper limits of the percentage by mass passing as specified by BS882 (Figure 3). However, the particle size distribution curve of the BCCB deviated from the percentage by mass passing envelop at sieve size $2.36 \mathrm{~mm}$.

The high numerical value of the coefficient of uniformity of the BCCB compared to the sand is indicative of a wider range of particle sizes. The gradation in Figure 2 reveals that the BCCB aggregate particles burnt up to $92^{\circ} \mathrm{C}$ and crushed is out of specification for use as fine aggregate. However, the coefficients of uniformity and curvature of $\mathrm{C}_{\mathrm{u}}=13.17$ and $\mathrm{Cc}=1.79$ respectively show that the BCCB particles are well-graded.

Table 1: Properties of aggregates and cement

\begin{tabular}{lcccc}
\hline \multicolumn{1}{c}{ Properties } & Coarse Aggregate (gravel) & Fine Aggregate (River sand) & BCCB & Portland limestone Cement \\
\hline Maximum size $(\mathrm{mm})$ & 20 & 1.18 & 5 & 3.14 \\
Specific gravity & 2.84 & 2.72 & 1.00 & \\
Bulk density $\left(\mathrm{kg} / \mathrm{m}^{3}\right)$ & 2375 & 2503 & 2088 & \\
Uniformity Coefficient $\left(\mathrm{Cu}_{\mathrm{u}}\right)$ & & 4.79 & 13.17 & \\
Coefficient of Curvature $\left(\mathrm{C}_{\mathrm{c}}\right)$ & & 0.73 & 1.79 & \\
\hline
\end{tabular}




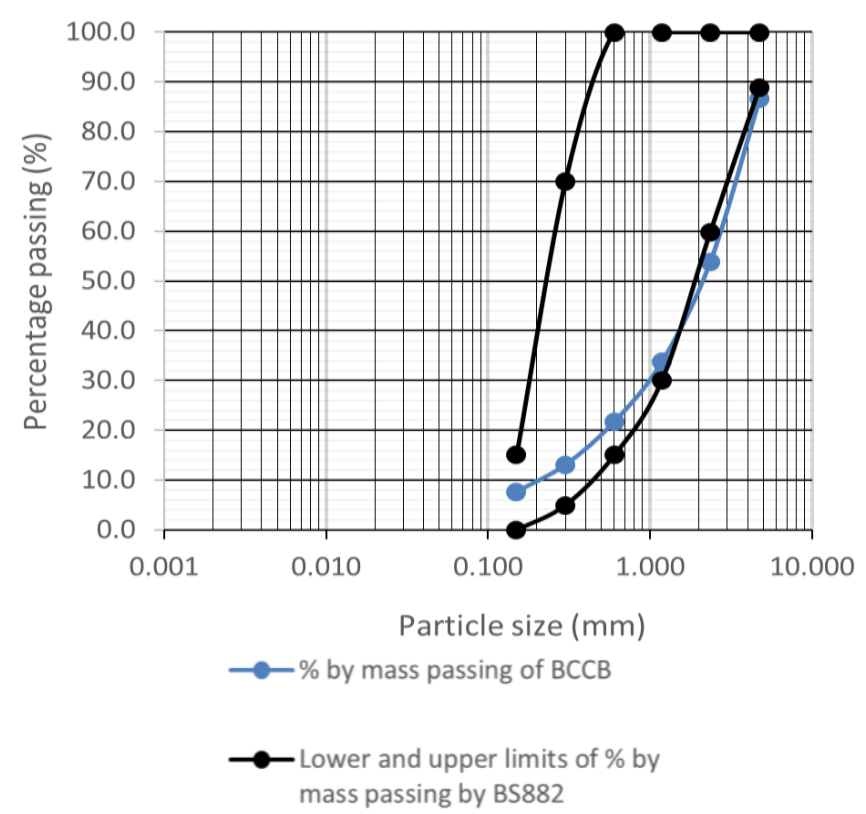

Figure 2: Particle size distribution curve of BCCB for grading to comply with BS882 overall limits for fine aggregates.

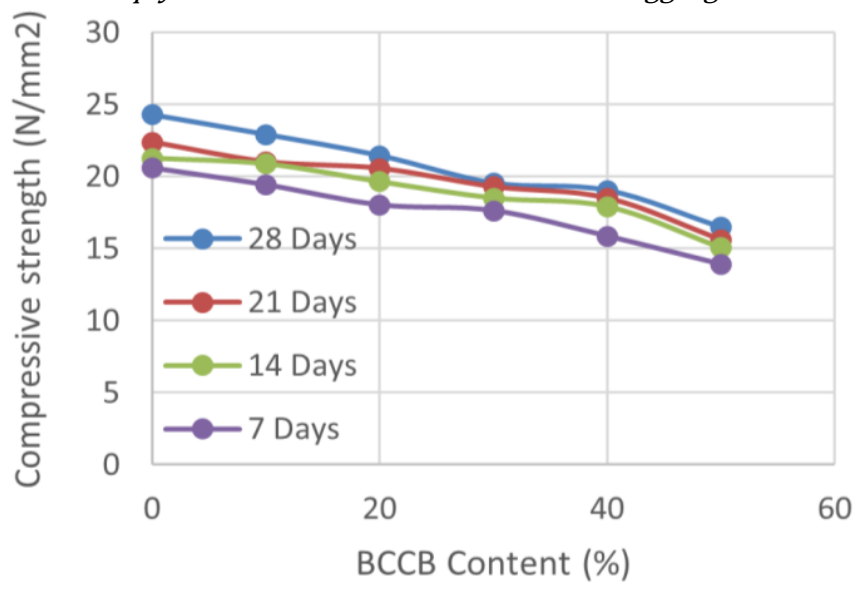

Figure 4: Compressive strength of concrete with BCCB as partial replacement for fine aggregate for concrete mix ratio of 1:2:4

\subsection{Effect of BCCB on Compressive Strength of Concrete}

The study clearly show that the compressive strength of the concrete responded with the variation in the percentage of the $\mathrm{BCCB}$, the concrete mix ratio and the age of curing as shown in Figures 4 and 5. It can be seen that the compressive strength of concrete reduces with increase in BCCB content. For the mix ratios of 1:2:4 and $1: 1 \frac{1}{2}: 3$ at 28 days curing age, it was observed that increase in the BCCB content beyond 40 and 50\%, respectively resulted to the reduction of the average compressive strength below $17 \mathrm{~N} / \mathrm{mm}^{2}$, which is the recommended minimum strength for use of concrete in structural works [23].

The compressive strength generally increases with increase in age of curing and decreases as the burnt and crushed cow bones (BCCB) content increases (Figures 3 and 4). Density is a measure of compactness and therefore the compressive strength of the concrete reduced with increase in BCCB content because the bulk

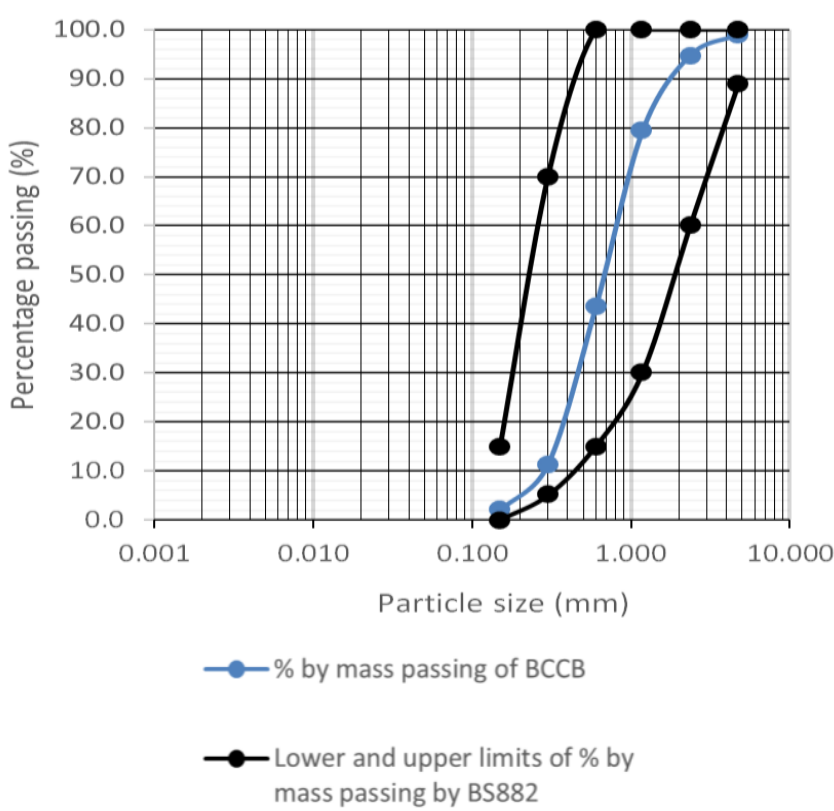

Figure 3: Particle size distribution curve of sand for grading to comply with BS882 overall limits for fine aggregates.

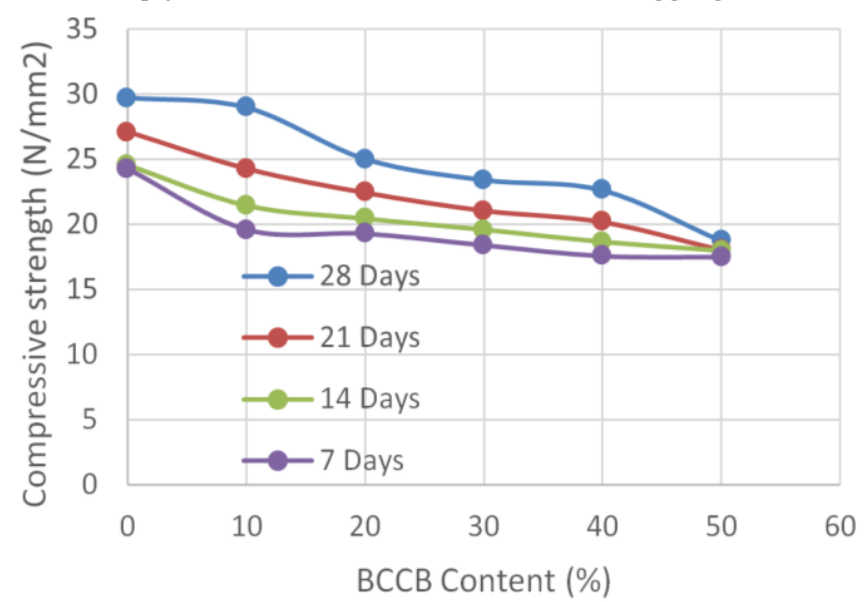

Figure 5: Compressive strength of concrete with BCCB as partial replacement for fine aggregate for concrete mix ratio of $1: 1 \frac{1}{2}: 3$

density (shown in Table 1) of BCCB is smaller than those of gravel and the river sand. A comparison of the compressive strengths for concrete mix ratio of 1:2:4 and 1: $1 \frac{1}{2}: 3$ show that the later mix ratio yielded higher compressive strengths (Figures 4 and 5).

\section{CONCLUSIONS}

The effect of burnt and crushed cow bones (BCCB) as partial replacement for fine aggregate in concrete was studied. The research revealed that the BCCB acted as a retarder in the concrete. Water-cement ratio increased with the increase in the percentage of the BCCB resulting in the reduction of the workability of concrete. The percentages of replacement of fine aggregates of 0,10 , $20,30,40$ and $50 \%$, respectively of BCCB considering $1: 2: 4$ and $1: 1 \frac{1}{2}: 3$ concrete mix ratios yielded average compressive strengths in $\mathrm{N} / \mathrm{mm}^{2}$ ranging from16.49 24.29 and $18.71-29.73$, respectively. This indicates that the compressive strength of concrete reduces as \% BCCB 
increases. The compressive strength generally increases with increase in age of curing. A comparison of the compressive strengths for concrete mix ratio of $1: 2: 4$ and 1: $1 \frac{1}{2}: 3$ show that the later mix ratio yielded higher compressive strengths. The minimum and maximum compressive strength of concrete at 50\% BCCB content for $1: 2: 4$ concrete mix ratio at 28 days curing age are $15.67 \mathrm{~N} / \mathrm{mm}^{2}$ and $17.67 \mathrm{~N} / \mathrm{mm}^{2}$, respectively. Similarly, the minimum and maximum compressive strength of concrete at $50 \%$ BCCB content for $1: 1 \frac{1}{2}$ : 3 concrete mix ratio at 28 days curing age are $17.78 \mathrm{~N} / \mathrm{mm}^{2}$ and 19.29 $\mathrm{N} / \mathrm{mm}^{2}$, respectively. For the mix ratios of $1: 2: 4$ and 1: $1 \frac{1}{2}: 3$ at 28 days curing age, it was observed that increase in the BCCB content beyond 40 and 50\%, respectively resulted to the reduction of the average compressive strength below $17 \mathrm{~N} / \mathrm{mm}^{2}$, which is the recommended minimum strength for use of concrete in structural works [23].

\section{REFERENCES}

[1] American Concrete Institute. ACI concrete terminology: An CI standard, Farmington Hills, U.S.A., 2013.

[2] Sika. Sika Concrete Handbook, Zurich, 2013.

[3] Kent Minerals and Waste Local Plan. Interchangeability of Construction Aggregates, Kent County Council, 2013.

[4] Karihaloo, B. L. and Tasdemir, M. A. Effect of Type and Volume Fraction of Aggregate on the Fracture Properties of Concrete In: de Borst R, Mazars J., Pijaudier-Cabot G, Van Mier JGM, editors, Proceedings of FRAMCOS-IV. Balkema pp.123-129, 2001.

[5] Abdullah A. A .A. Basic strength properties of Light weight concrete using agricultural wastes as aggregates. Proceedings of internal conference on LowCost Housing for developing countries, Roorkee India, 1984.

[6] Okafor F. 0. "Palm kernel shell as a lightweight aggregate for concrete". Cem. Con. Res., 18(6),pp. 901910, 1988.

[7] Basri H. B., Mannan M. A. and Zain M.F.M. "Concrete using waste oil palm shells as aggregate". Cem. Con. Res., 29, pp. 619-622, 1999.

[8] Mannan M. A. and Ganapathy C. "Mix design for oil palm shell concrete". Cem. Con. Res., 31, pp. 1323-1325, 2001.

[9] Teo D. C. L., Mannan M. A. and Kurian V. J. "Structural concrete using oil palm shell (OPS) as lightweight aggregate". TURK.J. Eng. Env. Sci., 30, pp. 251-257, 2006.
[10] Topcu I. B. "Semi lightweight concretes produced by volcanic slags". Cem. Con. Res., 27(1), pp. 15-21, 1997.

[11] Otunyo, A. W., Onwusiri, S. C. and Nwaiwu, N.“Effect of sugar cane juice on slump values, setting times and strength of concrete". Nigerian Journal of Technology., 34 (2), pp. $254-258,2015$.

[12] Egamana, S. and Sule, S. "Optimization of compressive strength of periwinkle shell aggregate concrete". Nigerian Journal of Technology., 36 (1), pp. 32 - 38, 2017.

[13] Adaba, C. S., Agunwamba, J. C., Nwoji, C. U., Onyia, O. E., Ozeh, S. "Comparative cost and strength analysis of cement and aggregate replacement materials". Nigerian Journal of Technology., 31 (2), pp. 111- 115, 2012.

[14]Javed A. B., Reyaz A. Q. and Dar A. R. "Machine crushed animal bones as partial replacement of coarse aggregates in lightweight concrete". ARPW Journal of Engineering and Applied Sciences, 7(9), pp. 1202-1207, 2012.

[15] British Standard Institution, BS 410. "Specification for test sieves". British Standard Institution, London, United Kingdom, 1986.

[16] British Standard Institution, BS 812 Parts103. "Testing Aggregates. Methods for determination of particle size distribution". British Standard Institution, London, United Kingdom, 1985.

[17] British Standard Institution, BS 1881 Part 116. "Method for determination of compressive strength of concrete cubes". British Standard Institution, London. United Kingdom, 1983.

[18] British Standard Institution, BS 812 Parts110. "Testing Aggregates. Methods for determination of Aggregate Crushing Value (ACV)". British Standard Institution, London, United Kingdom, 1990.

[19] British Standard Institution, BS 882. "Specification for aggregates from natural sources for concrete". British Standards Institute. London, United Kingdom, 1992.

[20] British Standard Institution, BS 1881 Part 102. "Method for determination of slump". British Standard Institution, London. United Kingdom. 1983.

[21] British Standard Institution, BS 1881 Part 108. " Testing concrete: Method for making test cubes from fresh concrete". British Standard Institution, London, United Kingdom, 1997.

[22] British Standard Institution, BS 1881 Part 114: Testing concrete: Methods for determination of density of hardened concrete". British Standard Institution, London. United Kingdom, 1983.

[23]ASTM C330 / C330M-14. "Standard Specification for Lightweight Aggregates for Structural Concrete". ASTM International, West Conshohocken, PA, 2014. 